\title{
Innovative Mine Closure Design Based on Observations of Mine and Natural Analogues
}

\author{
D.J. Williams The University of Queensland, Australia
}

J.T. Kline BHP Copper, San Manuel Mine, USA

\section{INTRODUCTION}

Conventionally, mine closure design is based on the desirability of a vegetated surface, preferably one that supports some future productive land use, such as the grazing of domesticated animals. A vegetated mined landform is also seen to be more aesthetically pleasing than a bare landform. However, mined landforms necessarily involve relatively steep slopes and, in arid climates, the best vegetative cover possible would be sparse. To achieve even a sparse vegetative cover in an arid climate would require the placement of a finegrained growth medium on the surface. However, a sparsely vegetated fine-grained surface cover on a relatively steep slope is prone to erosion (Williams, 2002). This is conventionally addressed by the construction of rock-lined contour and downslope drains to limit the velocity of runoff flow over the erosionprone surface cover. However, drains concentrate flow, making them, the inlet and outlet structures, and their surrounds, susceptible to erosion (Williams et al., 2004).

Observations of the outer slopes of San Manuel Mine's tailings storages in Arizona's arid climate showed them to be prone to piping erosion. Observations of covers of natural fine and coarse-grained alluvium placed on the tailings slopes showed that the alluvium suffered a washout of fines and sand during rainfall events, leading to the eventual loss of the cover and piping erosion of the exposed tailings. Observations of natural alluvial slopes showed that unless they are cemented or overlain by a dense, coarse-grained cap, they were also prone to erosion by storms. It became apparent that a rip rap cover, without constructed drains, would be required to reduce the risk of failure of the cover on the tailings outer slopes and exposure of the underlying tailings. The paper illustrates the observational approach employed in support of the recommended cover option for the tailings outer slopes.

\section{DESCRIPTION OF TAILINGS STORAGES}

The San Manuel Copper Mine tailings storages (Dams 1, 10, and 2 to 6 in order of increasing age) in Arizona, USA, are up to 50 years old, having closed down in 1999. The dams were operated in sequence to limit the rate of rise to $<3.0 \mathrm{~m} /$ year, achieving an average tailings dry density of 1.44 to $1.60 \mathrm{t} / \mathrm{m}^{3}$. The tailings storages cover 1323 ha in plan, with the $3(\mathrm{H}): 1(\mathrm{~V})$ outer slopes covering 274 ha, which are up to $90 \mathrm{~m}$ high and up to $275 \mathrm{~m}$ long. The watershed upstream of the tailings storages totals 1424 ha in plan.

The tailings storages were operated upslope from walls constructed from coarse tailings, with the decant water collected upslope by risers and drained to ponds at the toes of the storages. The walls were raised using the upslope method, initially by cycloning, and since the $1990 \mathrm{~s}$ by spigotting off the walls. The cycloned tailings are finer-grained and less oxidised and have a greater potential to generate acid than the spigotted tailings.

The foundation beneath the tailings storages slopes at about $4 \%$ towards the San Pedro River. Except for 5 and 6 Dams, the foundation beneath the tailings storages is relatively permeable (having a saturated hydraulic conductivity of about $10^{-4} \mathrm{~m} / \mathrm{s}$ ), capable of passing both rainfall percolation and seepage from the tailings. The main permanent watertable mounding occurs under the oldest 1 and 2 Dams. Relatively impermeable shale underlies 5 and 6 Dams, resulting in a perched watertable and seeps (diminishing since closure) fed by rainfall infiltration and tailings water, which contain about $2200 \mathrm{ppm}$ sulphide and are alkaline. 
Since closure, the ponding of rainfall runoff on the flat top surfaces of the tailings storages is limited to 1 or 2 months/year, with evaporation eliminating ponding for the remainder of the year. The decant risers have been left open, but little water reports to the sediment ponds.

San Manuel is located in an arid climate, experiencing 255 to $355 \mathrm{~mm}$ of rainfall annually, dominated by intense late summer monsoonal storms. The 100-year 24-hour storm is $98 \mathrm{~mm}$ and the 2-year, 5-minute storm is $8.4 \mathrm{~mm}$.

\subsection{Nature of Tailings and Natural Soils}

Borehole investigations carried out by SRK Consulting in February 2004 (SRK Consulting, 2004) indicated that the upper tailings are of low gravimetric moisture content (mass of water/mass of solids $<10 \%$ ) towards the surface, increasing to $30 \%$ at depth. Perched watertable were located within the tailings at between $24 \mathrm{~m}$ and $31 \mathrm{~m}$ below the surface, with the deepest water level in the oldest dam (1 and 2), indicating that the tailings continue to drain towards the foundation. Tailings produced up to 1991 were net acid generating (identifiable by their yellow colour, indicating that surficial oxidation has occurred), but with the addition of lime in the smelter from 1991 the tailings produced since were alkaline. The blowdown from the smelter stack, which reported to the tailings, was slightly acidic. However, overall the tailings are generally benign, and the foundation soils have a significant acid neutralisation potential.

SRK Consulting identified three geochemical zones with depth beneath the tailings beach:

- Surficial zone of active oxidation and secondary product precipitation, within about $6 \mathrm{~m}$ of the surface, comprising desiccated or drained tailings of $\mathrm{pH} 6.5$ to 7.5 , sulphate reducing with depth from about $250 \mathrm{mg} / \mathrm{l}$ towards the surface, and electrical conductivity from 1000 to $2500 \mu \mathrm{S} / \mathrm{cm}$, generally reducing with depth.

- Intermediate zone of partial oxidation, comprising moist tailings of pH 7 to 9 and electrical conductivity of about $500 \mu \mathrm{S} / \mathrm{cm}$.

- Zone of unoxidised, saturated or near-saturated tailings at depth, of $\mathrm{pH}$ of about 9 and electrical conductivity of about $500 \mu \mathrm{S} / \mathrm{cm}$.

On the outer slope of the tailings storages, the following geochemical zones were identified:

- Top of more recently-deposited, relatively fresh tailings showing little sign of oxidation, having $\mathrm{pH}$ from 6.0 to 8.2, sulphate reducing with depth from about $250 \mathrm{mg} / 1$ towards the surface, and electrical conductivity from 564 to $4990 \mu \mathrm{S} / \mathrm{cm}$, generally reducing with depth.

- Mid-height of partially oxidised, eroded tailings, having $\mathrm{pH}$ from 4.6 to 7.8 and electrical conductivity from 933 to $4390 \mu \mathrm{S} / \mathrm{cm}$.

- Toe of highly oxidised (yellow-orange), eroded tailings, having pH from 3.4 to 6.3 and electrical conductivity from 568 to $12400 \mu \mathrm{S} / \mathrm{cm}$.

The natural soils in the region comprise coarse-grained alluvium in the vicinity of 5 and 6 Dams, and finegrained alluvium (up to about $25 \mathrm{~mm}$ in size) elsewhere. Figure 1 shows typical particle size distribution curves for the natural fine-grained alluvium (Unified Soil Classification SM and SC) and coarse-grained alluvium (Unified Soil Classification GM and GC). The fine-grained alluvium is dominated by rounded, sand-sized particles, with about $20 \%$ fines, while the coarse-grained alluvium is a sandy gravel with 10 to $15 \%$ fines. Also shown on Figure 1 are typical particle size distribution curves for the tailings at the wall, on the beach and in the slimes pond. The San Manuel tailings are silty sand-sized on average (see Figure 1), with the pond tailings (slimes) somewhat finer-grained than the beach and wall tailings, with saturated hydraulic conductivities of about $10^{-6} \mathrm{~m} / \mathrm{s}$ and $10^{-5}$ to $10^{-4} \mathrm{~m} / \mathrm{s}$, respectively. 


\section{OBSERVATIONS OF TAILINGS AND NATURAL ANALOGUES}

\subsection{Tailings Outer Slopes}

Figure 2 shows the unreclaimed, newer, upper bench of the outer slope of 3 and 4 Dam, showing only minor erosion. Figure 3 shows the unreclaimed outer slopes of the older 10 Dam, showing full-height rilling, tunnel erosion and gullying, and oxidation of the tailings.

Figure 4 shows the revegetated fine-grained alluvium cover placed on the outer slope of 1 and 2 Dam in 2002, showing a reasonable vegetative cover and little erosion. Figure 5 shows the now poorly vegetated and badly eroded fine-grained alluvium cover placed on the outer slope of 1 and 2 Dam in 1991.

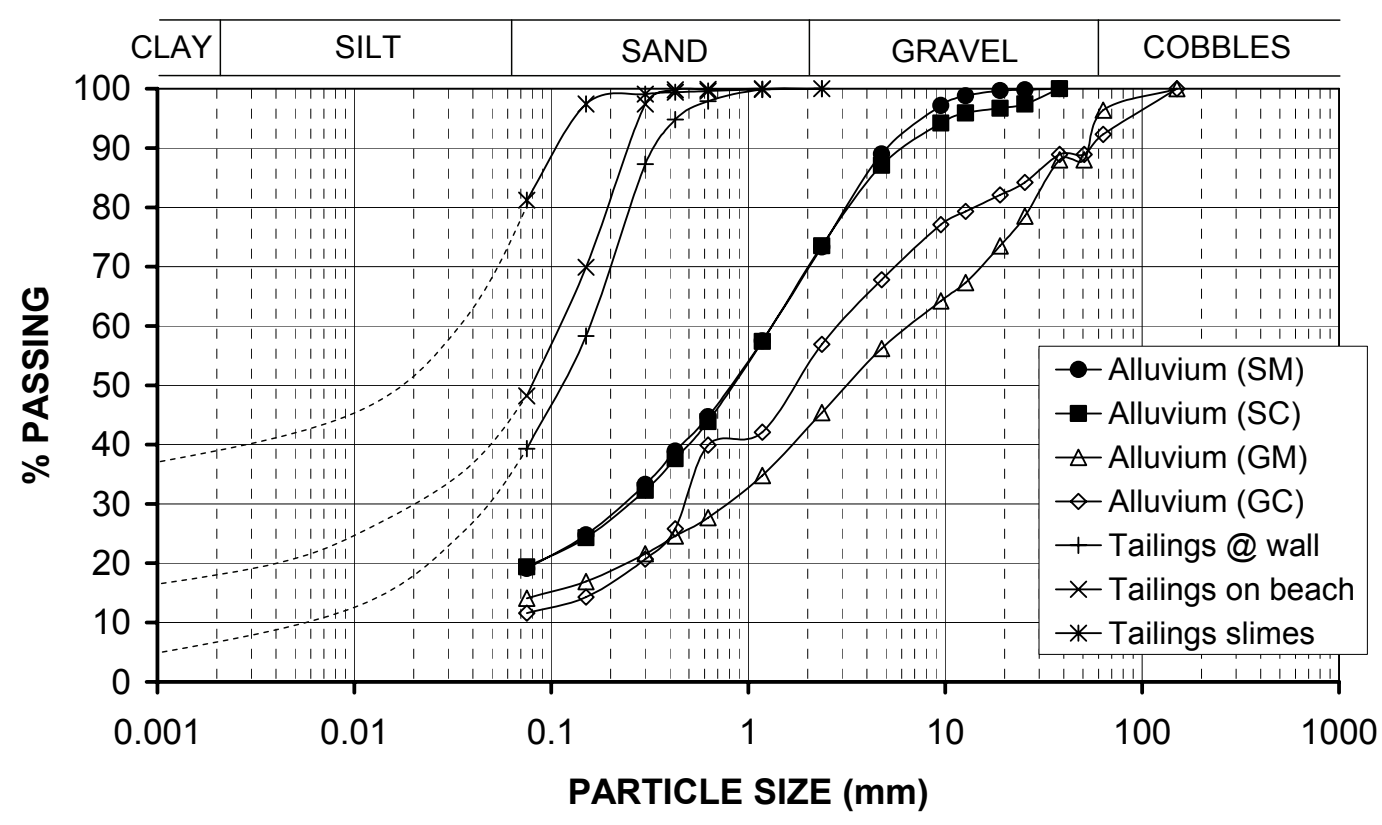

Figure 1 Typical particle size distribution curves for tailings and natural alluvium

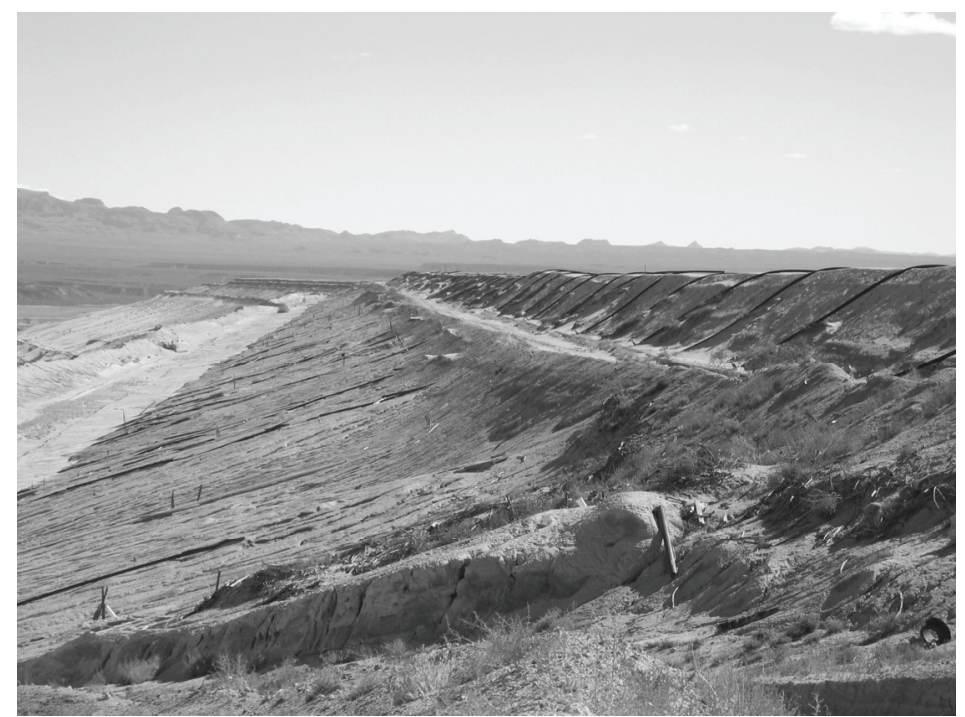

Figure 2 Unreclaimed, newer, upper bench of outer slope of 3 and 4 Dam, showing only minor erosion 


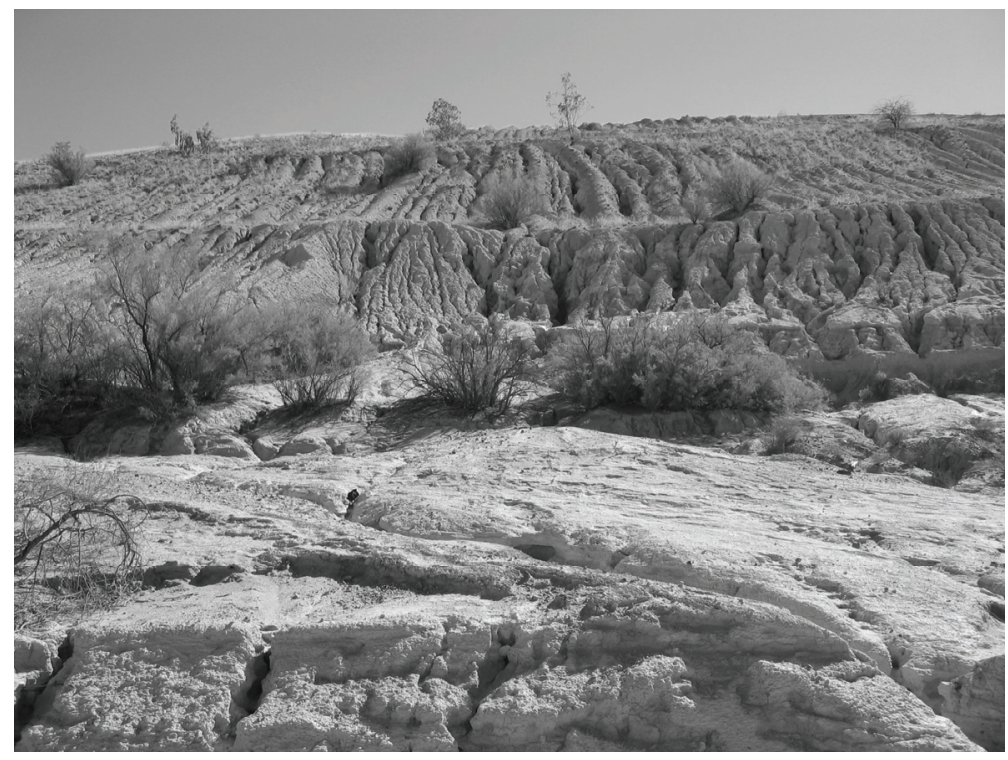

Figure 3 Unreclaimed, older, outer slope of $10 \mathrm{Dam}$, showing full-height rilling, tunnel erosion and gullying

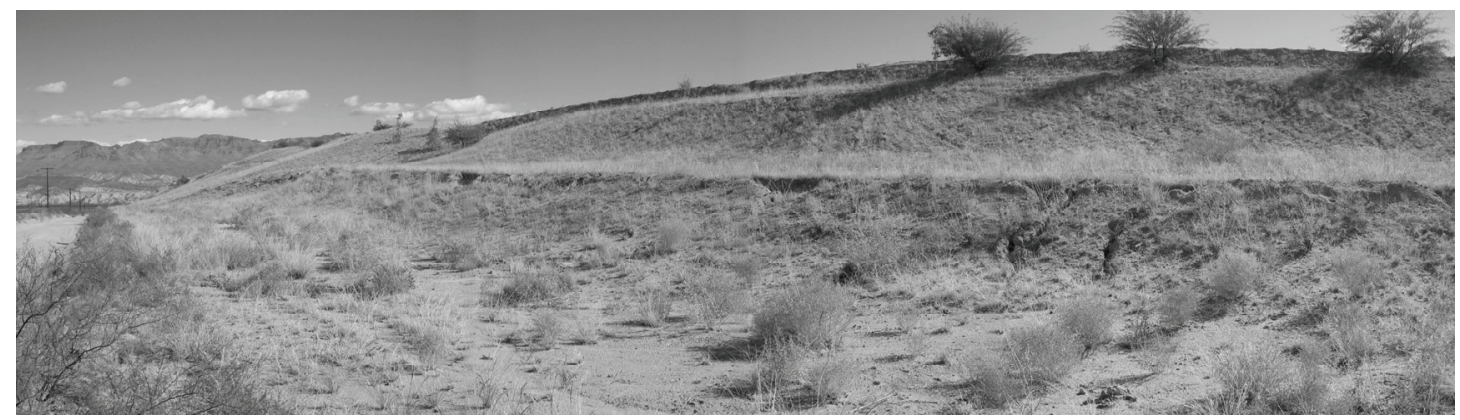

Figure 4 Revegetated fine-grained alluvium cover placed on outer slope of Dam 1 and 2 in 2002

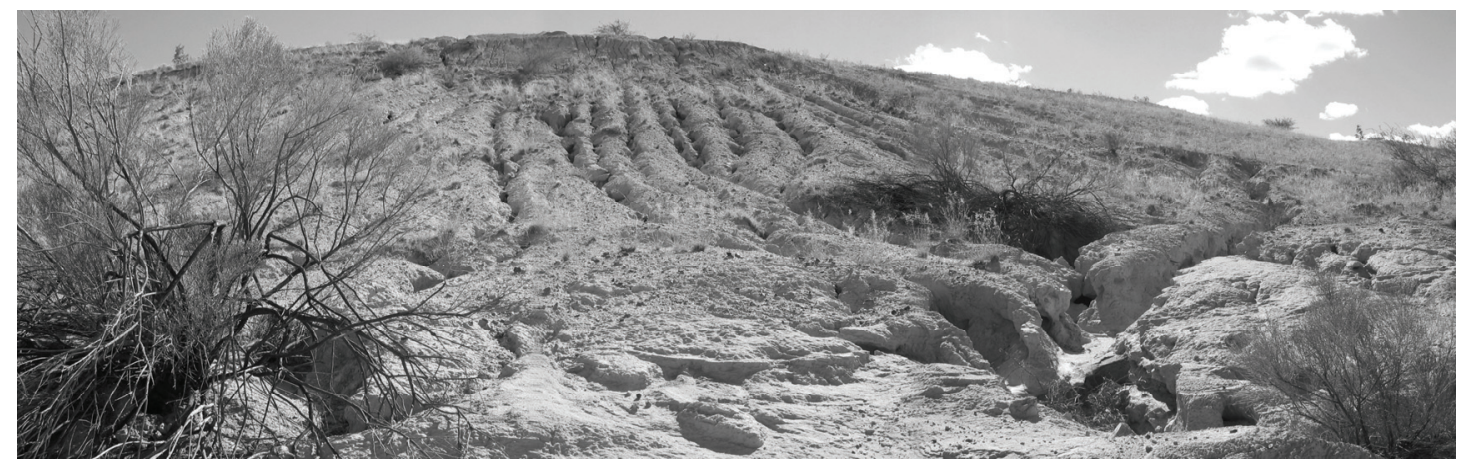

Figure 5 Now poorly vegetated and badly eroded fine-grained alluvium cover placed on outer slope of 1 and 2 Dam in 1991 
Figure 6 shows the poorly vegetated and gully-eroded coarse-grained alluvium cover placed on the outer slope of 6 Dam in 1991. The outer slopes of the San Manuel tailings storages show gullying developed from tunnel erosion of the tailings, which appears to follow the sequence:

- Ponding on benches, or surface rilling of uncovered tailings or of the cover, leading to increased and concentrated infiltration into the underlying erodable tailings.

- Initiation of tunnel erosion into the tailings at these infiltration points.

- Development of erosion tunnels.

- Emergence of erosion tunnels at the next bench downslope or at the toe of the slope.

- Collapse of the tunnels leading to gullies.

- Development of the gullies upslope and downslope, ultimately extending the full height of the slope, accompanied by a deepening and widening.

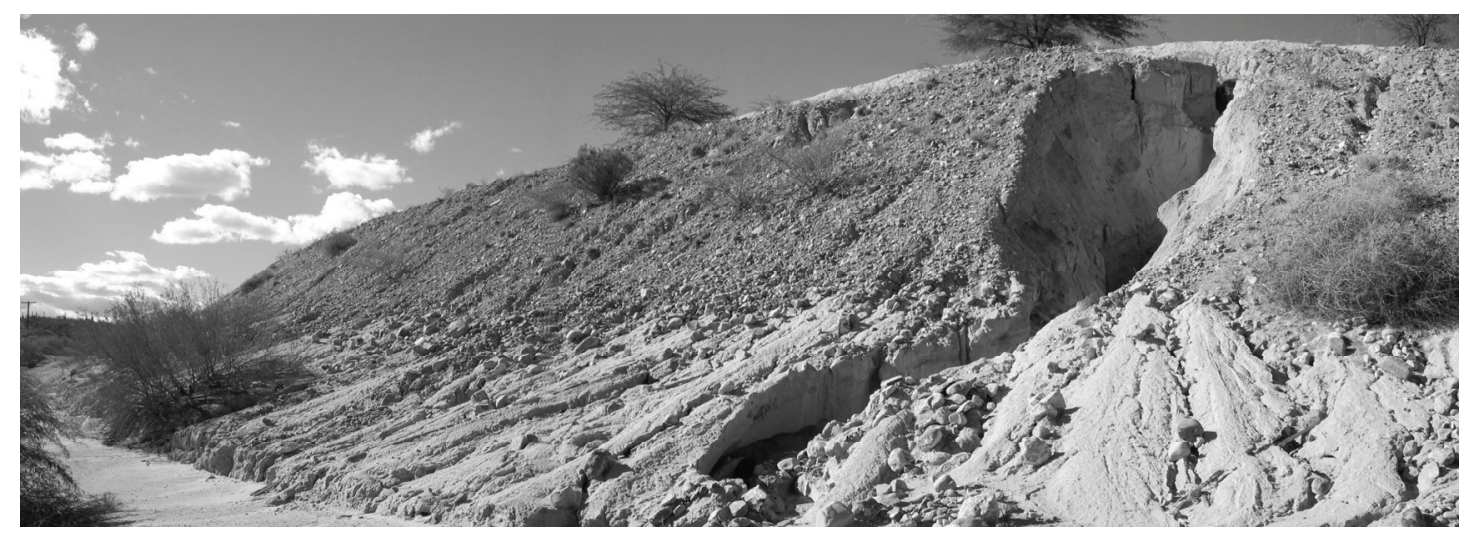

\section{Figure 6 Poorly vegetated and gully-eroded coarse-grained alluvium cover placed on outer slope of 6 Dam in 1991}

In relation to the outer slopes of the San Manuel tailings storages, it is likely that the majority of incident rainfall runs off, but benches (including drainage benches) that allow the ponding of water increase and concentrate infiltration into the erodable tailings, resulting in tunnel erosion and gullying. It appears that a fine-grained alluvium cover on the slope will initially revegetate, but rills will develop that promote tunnel erosion and gullying of the tailings, and the loss of the cover causes a loss of vegetation within about 10 years. A coarse-grained alluvium cover on the slope promotes only limited revegetation, and rills develop, leading to tunnel erosion and gullying of the tailings.

\subsection{Natural Analogue Slopes}

Figures 7 and 8 show natural, eroded, fine-grained and coarse-grained alluvial landforms in the vicinity of San Manuel. Figure 9 shows a natural cemented coarse-grained cap over erodable fines, exposed in a road cutting. The thickness of the cemented cap is typically about $0.6 \mathrm{~m}$, and up to about $1 \mathrm{~m}$, but diminishes to a very limited thickness beneath a sloping ground surface.

The natural analogues in the vicinity of San Manuel demonstrate the lack of vegetation on steep fine-grained alluvium, due to ongoing erosion at high rates, and reasonably stable and somewhat vegetated, steep coarsegrained alluvium slopes, possibly protected by a cemented coarse-grained cap or dense coarse-grained alluvium. 


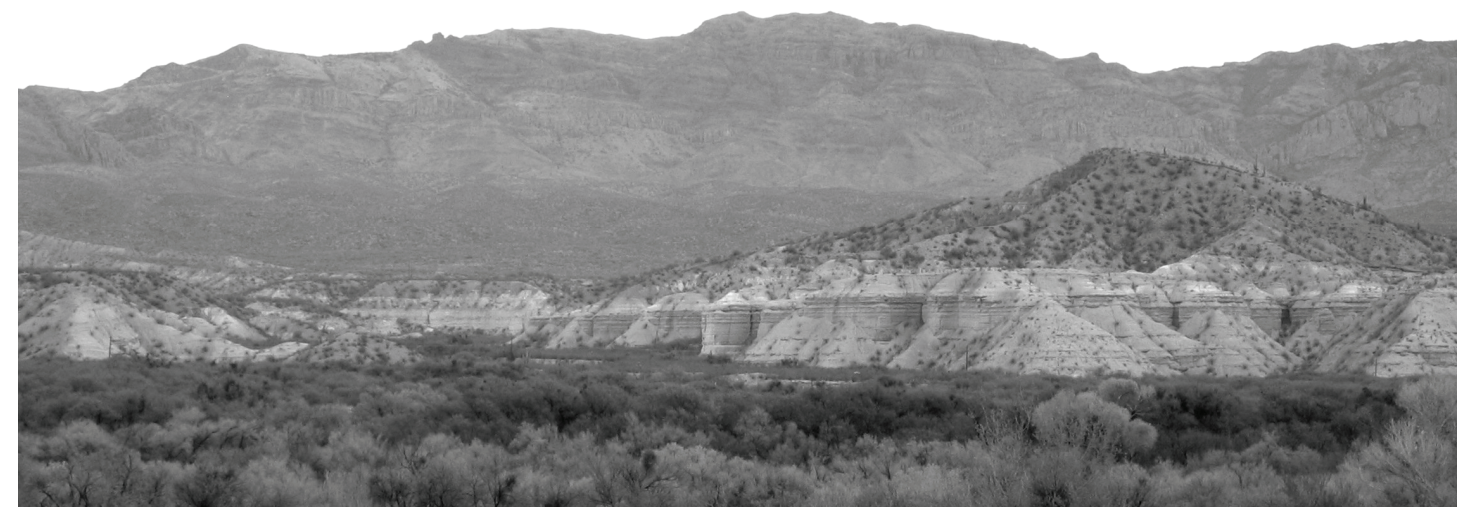

Figure $7 \quad$ Natural, eroded, fine-grained alluvium landform

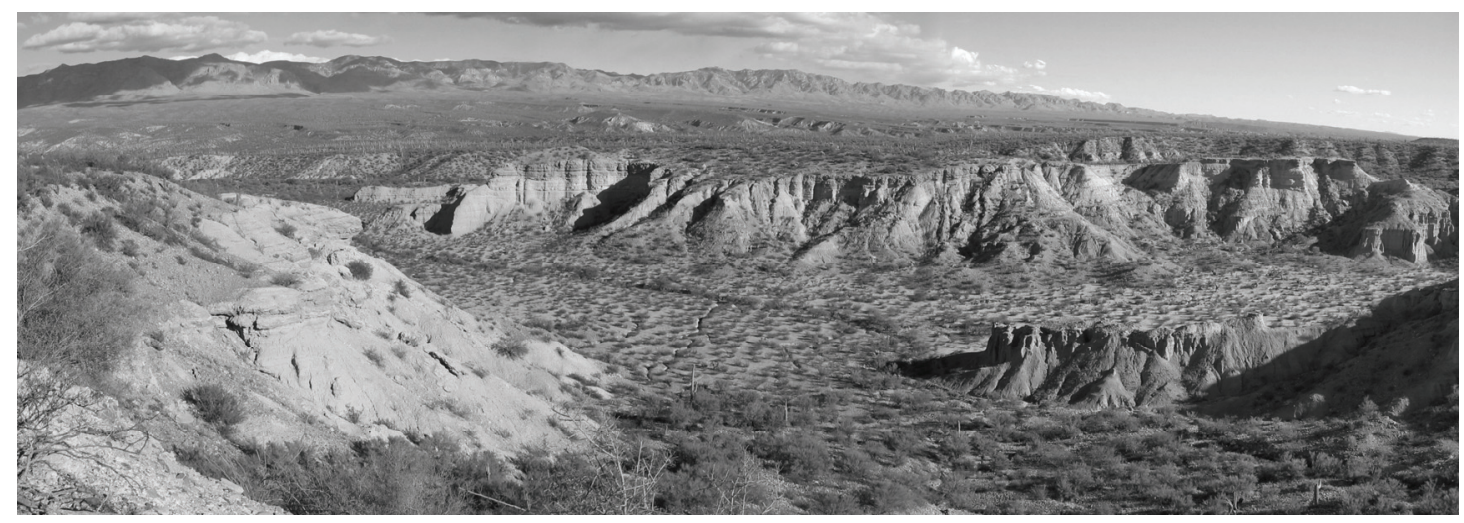

Figure 8 Natural, eroded, coarse-grained alluvium landform

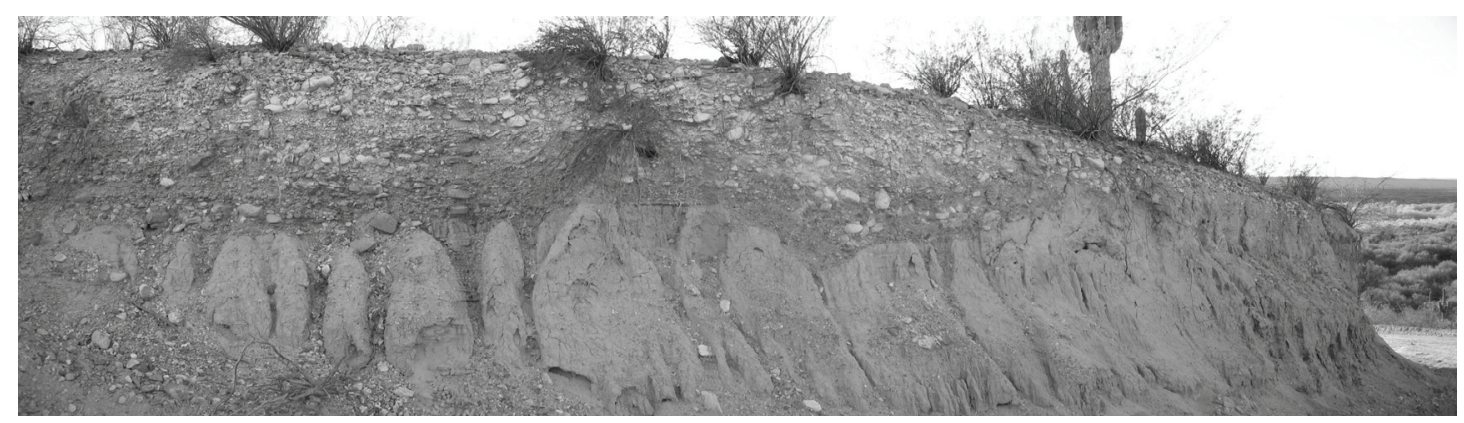

Figure $9 \quad$ Natural cemented coarse-grained cap over erodable fines

\section{ORIGINAL AND REFINED CLOSURE DESIGNS}

\subsection{Drivers for Reclamation of Tailings Storages in Arizona}

The drivers for the reclamation and closure of tailings storages in Arizona are the following:

- Minimising contact between rainfall runoff and potentially contaminating tailings, by diverting clean runoff around the tailings storage, and placing a sustainable cover over the tailings (beach and outer slope). 
- Minimising rainfall infiltration into potentially contaminating tailings, by avoiding the ponding of rainfall runoff on the covered tailings beach.

- Removing rainfall runoff from the outer slope, with a high-risk predisposition for rock-lined drainage benches and downslope drains.

- Revegetating the cover to reduce surface erosion, decrease deep drainage of rainfall via transpiration, to allow a post-reclamation grazing land use, and for aesthetic reasons.

\subsection{Regulatory Environment}

In Arizona, the state regulates Federal Laws. The valuable groundwater resource is regulated under an Aquifer Protection Permit, using Best Available Demonstrated Control Technology (BADCT). Regulation may be Prescriptive or Individual, the latter case requiring demonstration that BADCT is followed. The aim is to avoid the ponding of rainfall runoff on the tailings to minimise infiltration and the seepage of potentially contaminated water to the groundwater. Surface water is regulated via discharge limitations, which vary along the length of the San Pedro River, depending on beneficial use (acceptable quality for fish, migratory birds and drinking water generally govern). Legal requirements exist for surface water cover turbidity, $\mathrm{pH}$, Electrical Conductivity (EC) and dissolved metals.

The design approach adopted for the closure of the tailings storages followed BADCT, with a Reclamation Plan that addresses air quality, the Clean (Surface) Water Act, and BHP Billiton's semi-qualitative Risk Management process (EWRM), which considers a range of scenarios and assigns a Risk Ranking. Clean rainfall runoff diversions around the tailings storages will be retained and rainfall incident on the covered tailings will be discharged to sediment ponds prior to release. Groundwater monitoring wells located downstream of the tailings storages show elevated sulphate, although this is currently not regulated. The runoff from the tailings is high in sulphates and dissolved metals, requiring that the tailings be covered to prevent direct contact by rainfall post-closure. The cover must be relatively resistant to surface erosion and piping by rainfall runoff and infiltration, respectively, and must prevent piping of the underlying tailings. The potential for dust generation off the tailings also requires that they be covered and revegetated.

\subsection{Preliminary Closure Design Criteria}

The preliminary closure design criteria adopted by the mine and their consultants SRK Consulting were:

- An individual, rather than a prescriptive, closure design for a 100-year design life.

- Stay out of jurisdictional waters, by retaining, undisturbed, the permitted clean rainfall runoff diversions, which are designed to accommodate the 100-year flow.

- Grout the decants, and eliminate the ponding of rainfall runoff on the tailings beach, by mounding with fine-grained alluvium, above a geotextile, over the remnant ponds to cause them to drain around their perimeters towards borrow pits excavated upslope, from which excess water will discharge to a spillway, with the remainder seeping into the foundation or evaporating.

- Cover the tailings to minimise rainfall infiltration and dust.

- Engineering design criteria for the tops of the tailings storages included:

- Tailings beach slope averaging $0.25 \%$ (up to $0.5 \%$ ), over a foundation slope of about $4 \%$ in the reverse direction.

- Probable Maximum Precipitation (PMP) of about $400 \mathrm{~mm}$ would result in a $0.9 \mathrm{~m}$ deep flow over a $120 \mathrm{~m}$ wide spillway, at an elevation of $1.5 \mathrm{~m}$ below the highest point of the tailings.

- All tailings beaches covered with a minimum $0.3 \mathrm{~m}$ of fine-grained alluvium to limit dusting and for moisture retention to allow revegetation (neither the tailings themselves nor the coarse-grained alluvium support much vegetation), which has been predicted to reduce rainfall infiltration by $30 \%$. 
- Engineering design criteria for the outer slopes of the tailings storages included:

- Overall slopes of $3(\mathrm{H}): 1(\mathrm{~V})$ for the outer faces of the tailings storages, with maximum slope lengths of 260 to $275 \mathrm{~m}$ for a maximum $90 \mathrm{~m}$ depth of tailings.

- The removal of the upper benches that pond rainfall runoff, the construction of rip-rapped ( $0.3 \mathrm{~m}$ thick over $0.3 \mathrm{~m}$ of fine-grained alluvium) drainage benches at $45 \mathrm{~m}$ intervals down the slope (comprising $30 \%$ of the slope area), directed towards rock-lined downslope drains at regular intervals of $300 \mathrm{~m}$, and a cover over the tailings between the drainage benches comprising $0.3 \mathrm{~m}$ of coarse-grained alluvium over $0.3 \mathrm{~m}$ of fine-grained alluvium, with reliance on revegetation of the coarse-grained alluvium for some protection against surface erosion.

- Specification of rip rap.

- Establish downstream (well) points of compliance.

\subsection{Refined Closure Design for Tailings Outer Slopes}

The original closure design proposed for the tops of the tailings storages was adopted. Although the tailings do not support direct revegetation, a fine-grained alluvium cover can be successfully revegetated, and may reduce infiltration through transpiration. Sufficient cover thickness is required to sustain revegetation and to allow for any minor erosion losses that may occur. To minimise infiltration into the underlying tailings, and so minimise potentially contaminated seepage into the foundation, the ponding of rainfall runoff on the cover should be avoided.

However, observations of mine and natural analogues suggested a high probability that the closure design originally proposed for the outer slopes of the tailings storages would fail, pointing to the following refined closure design for the slopes.

- Continuous 3(H):1(V) slope.

- A $0.3 \mathrm{~m}$ thick layer of fine-grained alluvium over the entire slope, with an average $230 \mathrm{~mm}$ of rip rap protection (nominally $150 \mathrm{~mm}$ maximum size quarry run, increasing in thickness down the slope from $150 \mathrm{~mm}$ at the crest to $300 \mathrm{~mm}$ at the toe), providing a dense, coarse-grained cover, since cementation is impractical. The coarse-grained alluvium cover originally proposed for the slopes between the drainage benches would promote only poor revegetation, and would be prone to rilling erosion, with the potential for concentrated infiltration into the underlying tailings leading to piping erosion.

- No drainage benches or downslope drains, and no reliance on revegetation of the rip rap. The drainage benches and downslope drains would concentrate runoff and would also be susceptible to undercutting. Also the drainage benches would be prone to silting up and differential settlement, which would lead to ponding of water, and/or overtopping.

- Rip rap should continue over the crest, and in toe drains constructed downstream of the walls to handle any runoff.

\section{$5 \quad$ RIP RAP AND COARSE ALLUVIUM EROSION TRIALS}

To confirm the relative merits of the refined outer tailings slope closure designs, erosion trials were carried out, testing coarse-grained alluvium directly over tailings, and rip rap over fine-grained alluvium overlying tailings. The results of the trials are shown pictorially in Figure 10 for the simulation of the 100-year, 24hour storm at the base of a $275 \mathrm{~m}$ long 3:1 slope. For this extreme rainfall event, Figure 10 highlights the extensive washing out of fines and sand from the coarse-grained alluvium, while the rip rap has experienced negligible erosion.

At the nearby Old Dominion Mine, a cover comprising $0.6 \mathrm{~m}$ of colluvium, overlain by $0.15 \mathrm{~m}$ of rip rap comprising screened colluvium ( $75 \mathrm{~mm}$ maximum size) was prescribed by the USEPA for the outer slope of the tailings storage. No attempt was made to revegetate the rip-rapped slope. Downslope drains were 
included and were concrete-lined. The cost of this cover was about \$US 200000 ha. In the first 10 months after the cover was completed, the only maintenance required was where a drain had been undercut.

\section{SELECTION AND IMPLEMENTATION OF ADOPTED CLOSURE DESIGN}

From the results of the erosion simulations (highlighted on Figure 10), it was decided to use coarse-grained alluvium over fine-grained alluvium for the upper third of the outer slope of the tailings storages and rip rap over fine-grained alluvium for the lower two-thirds of the outer slope. The justification for the selection of a coarse-grained alluvium cover over the upper third of the slope was its acceptable performance over this length of slope from the erosion trial conducted for the corresponding simulated design rainfall runoff. This approach produced significant cost savings, making the cost of constructing the refined outer tailings slope closure design comparable to that of the original design at about \$US $80000 / \mathrm{ha}$, while retaining the substantial cost savings for ongoing maintenance. Figure 11 shows the early stages of the construction of the slope cover, with the tailings slope having been dozed to infill any erosion gullies, the fine-grained alluvium sub-layer and coarse-grained alluvium cover on the upper third of the slope having been placed, and the rip rap cover over the lower two-thirds of the slope in the process of being placed.

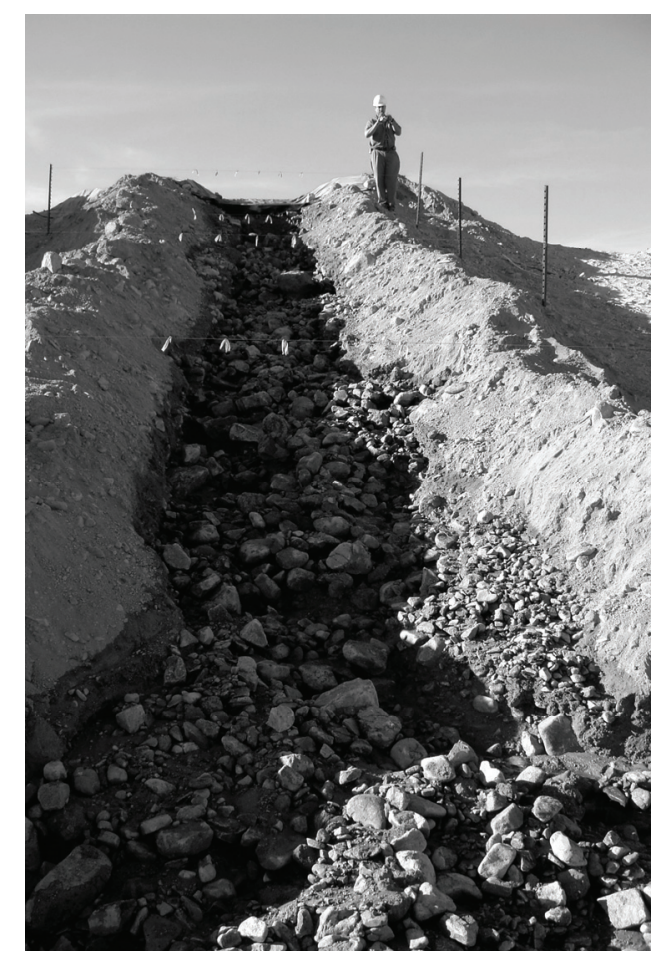

(a) coarse-grained alluvium

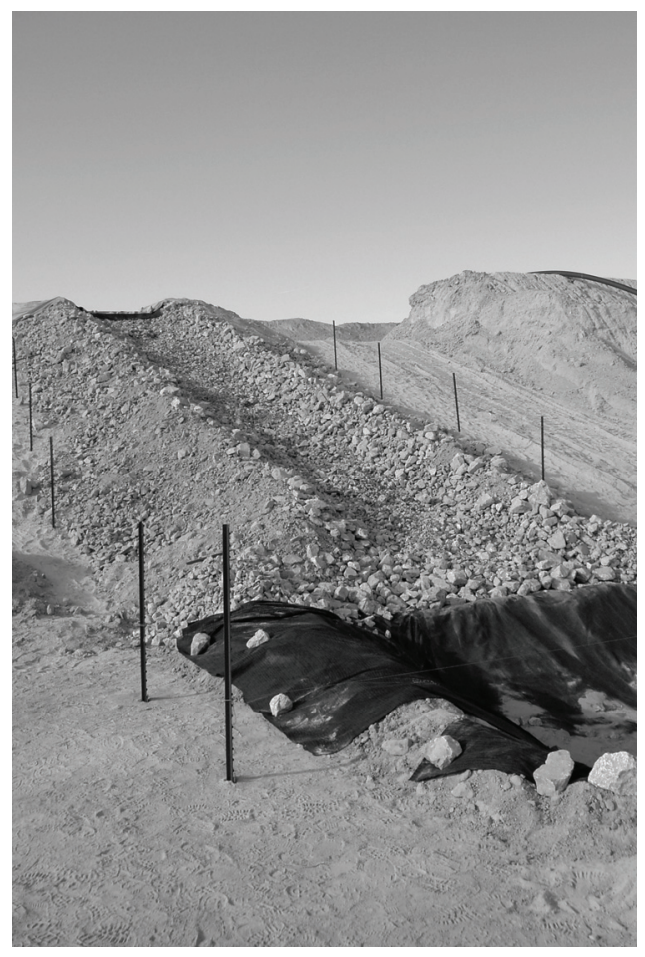

(b) rip rap

Figures 10 Erosion of (a) coarse-grained alluvium (showing extensive washing out of fines and sand) and (b) rip rap (showing negligible erosion) 


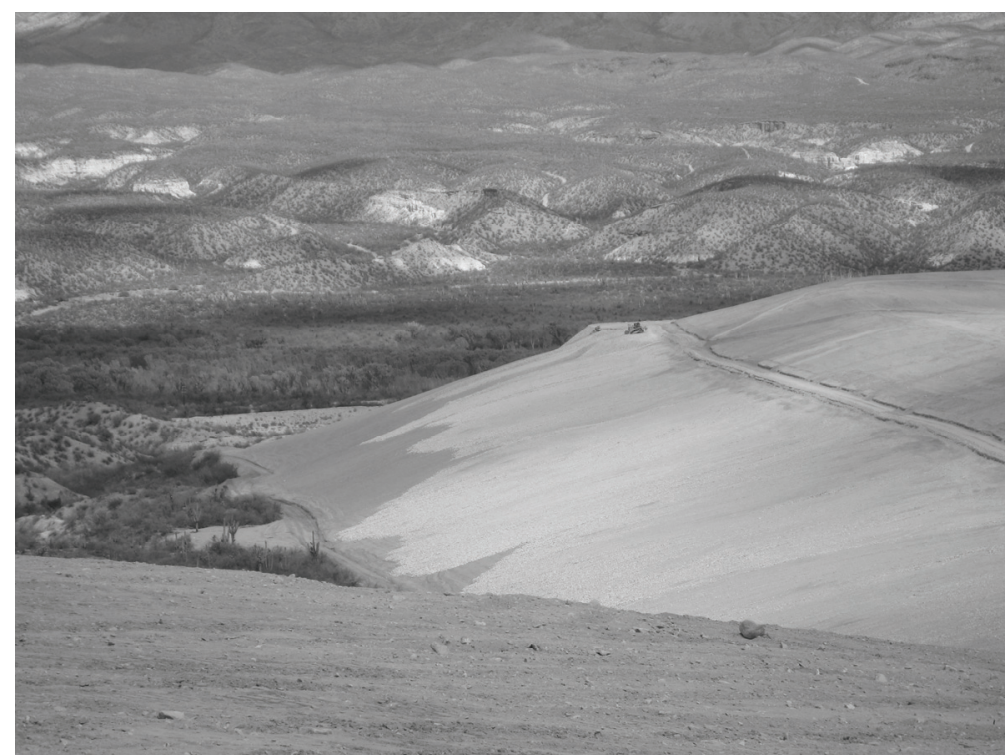

\section{Figure 11 Construction of cover on outer tailings slope}

\section{$7 \quad$ CONCLUSIONS}

Observations of San Manuel Mine's tailings and fine and coarse-grained alluvium covers in Arizona's arid climate showed them to be prone to piping erosion, which applies also natural alluvial slopes unless they are cemented or overlain by a dense, coarse-grained cap. It became apparent that a rip rap cover, without constructed drains, would be required to reduce the risk of failure of the cover on the outer tailings slopes and exposure of the underlying tailings.

\section{ACKNOWLEDGEMENTS}

The authors gratefully acknowledge BHP Copper and the San Manuel Mine, subsidiaries of BHP Billiton, for allowing the study described in this paper to be presented. Information supplied by SRK Consulting is also gratefully appreciated.

\section{REFERENCES}

SRK Consulting (2004) Private communication.

Williams, D.J. (2002) Engineering closure of an open pit gold operation in a semi-arid climate. International Journal of Surface Mining and Reclamation, Special Edition on Mining and the Environment, 16(4), pp. 270-288.

Williams, D.J., Loch, R.J. and Vacher, C. (2004) Risk assessment applied to tunnel erosion of mine spoils. Proceedings 11 th International Conference on Tailings and Mine Waste '04, Vail, Colorado, 10-13 October 2004, pp. 63-70. 